\title{
Proximate composition of para-grass (Brachiaria mutica) produced in integrated fish-fodder culture system
}

\author{
MR Alam ${ }^{1 *}$, MM Haque $^{2}, \mathrm{KR} \mathrm{Sumi}^{1}, \mathrm{MM} \mathrm{Ali}^{2}$ \\ ${ }^{1}$ Department of Aquaculture, Patuakhali Science and Technology University, Patuakhali 8602, Bangladesh; \\ ${ }^{2}$ Department of Aquaculture, Bangladesh Agricultural University, Mymensingh 2202 Bangladesh
}

\begin{abstract}
An experiment was conducted to evaluate the effects of Pangasius pond sediment on the nutrient uptake by para-grass (Brachiaria mutica) during the period from March to October, 2011 in a Pangasius farm, Dhanikhola, Trishal, Mymensingh. Initially soil chemistry of Pangasius pond sediment and para-grass producing virgin soil was analyzed at the laboratory. The fodder was cultivated at various level of inorganic fertilizer with Pangasius pond sediment having three replications in each treatment. The size of each replication was $25 \mathrm{~m}^{2}(5 \mathrm{~m} \times 5 \mathrm{~m})$. The fodder was harvested at the pre-flowering stage (45 days after transplantation). After first cutting, experimental plot was irrigated, and again after 45 days of first cutting second cutting was done. After proper collection and preparation the para-grass samples and rice straw, their proximate composition analysis was done. The nutrient content of para-grass was also compared with rice-straw being used as dairy feed. The analytical results indicated that the nutrients content of Pangasius pond sediment was higher than the virgin soil which was the stimulating factor for para-grass growth and production. The basic nutrients such as crude lipid and protein content of paragrass were found increasing from first to second sampling. However, crude lipid and protein of para-grass at second sampling was found much higher than those of rice straw. Application of Pangasius pond sediment as alternative source of fertilizer enriched nutrient content of para-grass much higher than those of rice straw. Therefore, it could be argued that higher level of lipid and protein content of paragrass is the stimulating factor to dairy cattle production under integrated aquaculture-fodder grass production using Pangasius pond sediment.
\end{abstract}

Key words: Pangasius pond sediment, para-grass, Fodder Production, Integrated Aquaculture.

Bangladesh Animal Husbandry Association. All rights reserved.

Bang. J. Anim. Sci. 2015. 44 (2): 113-119

\section{I ntroduction}

Bangladesh is the fifth highest aquaculture fish producing country of the world (FAO, 2013). During the last two decades aquaculture has developed in this country tremendously, especially in Mymensingh, Jessore and Comilla regions. Various types of indigenous fishes such as, Indian major carp, stinging catfish, walking catfish etc and exotic fishes such as, Chinese carp, climbing perch, pangas catfish, Mozambique tilapia etc. are cultured. Pangasius farming has been introduced in Bangladesh at nearly 1990. Now-a-days it becomes an industry of intensive culture system with annual production of $0.3-0.4$ million MT. Pangasius is cultured in shallow pond with high stocking density and large amount of feed input. Feeding is done based on commercial and/or farm made pellet feed which has sinking nature like as light stone. According to the different fish farmers of Mymensingh district, in the intensive culture system two kilogram pellet feed is required to produce one kilogram of Pangasius. A significant proportion of feed is not eaten by the fish and due to its sinking nature and it settle down on bottom as sediment. Excreta of fish and other organic and inorganic materials of feeding also deposit on bottom soil. Unutilized feed, excreta and other organic materials make a thicker layer over pond bed. An experiment showed that 10-12 kg unutilized feed can make a layer of $1 / 2$ inch per square meter (Haque, 2011). This type of deposition creates some problems in Pangasius pond, for example creates water quality problems, enhances the 


\section{Proximate composition of para-grass}

algal bloom production etc. Thus the farmers require removing pond bottom mud but this work is expensive and laborious and also useless to them.

Olah et al. (1994) reported that $90 \%$ of the nitrogen $(\mathrm{N})$ applied to fish pond accumulated in the sediment. Similarly, Boyd (1995) showed that a higher fraction of phosphorus (P) compounds applied to the ponds also ended up in the sediment. A research showed that only $30 \%$ of $\mathrm{N}$ of feed applied to pond was absorbed by fish and reaming $70 \% \mathrm{~N}$ ended up in the sediment (Haque, 2011) and also reported that amount of $\mathrm{N}$ accumulation per hectare is about $4000 \mathrm{~kg}$ which is equivalent to about $8500 \mathrm{~kg}$

\section{Materials and Methods}

\section{Site selection}

The experiment was carried out to find the effective and alternative use of Pangasius pond bottom soil during the period from March to October, 2011 in a Pangasius farm named 'Ma Fishery' at Dhanikhola Union under Trishal Upazila, Mymensingh, Bangladesh. Mymensingh is as the homeland of Pangasius farming in Bangladesh. A considerable number of farms of Mymensingh were found at Trishal with longer experience. They were found of experienced with positive and negative impacts of aquaculture. While farm owner was contacted, he realized and felt interested which was helpful to conduct the experiment. The geographical location of experimental site was $90^{\circ} 22^{\prime} 54.02 "$ E longitude and $24^{\circ} 37^{\prime} 20.02^{\prime \prime} \mathrm{N}$ latitude and farms site situated at $90^{\circ} 22^{\prime} 53.08^{\prime \prime} \mathrm{E}$ longitude and $24^{\circ} 37^{\prime} 20.30^{\prime \prime} \mathrm{N}$ latitude. Surrounding area of experimental site contains huge number of Pangasius farms (Figure 1).

\section{Farm characteristics}

The selected Pangasius farm has been running since 2003 which was mainly a grow-out farm. The area of the farm was about 2 ha and number of pond was 10. Each pond size was about 45 decimal with average of $1-1.5 \mathrm{~m}$ water depth. The Pangasius were fed with farm made urea fertilizer. For the fruitful use of this resource, an experiment was designed in this research to produce para-grass in integrated fish-fodder culture system. The folder grass production is a critical issue of local dairy farming because a sharp decrease of grazing field negatively affected on dairy production, thus the nation is increasingly depending on the imported milk in Bangladesh. In this context, the objectives of the study were to assess nutrient potential of Pangasius pond sediment to find out the proximate composition of paragrass produced in integrated fish fodder culture system; and to compare the nutritional quality of para-grass and common feed (rice-straw) being traditionally fed to cattle.

and commercial pellet feed. Groundwater was the main source of water with limited water exchange rate. About $120,000 \mathrm{~kg}$ feed was used during the year 2010 causing deposition of pond sediments. The sediments of pond bottom were removed 2-3 years interval and used to repair the pond dikes. Electricity supply and good communication system were functioning to the farm area.

\section{Experimental design}

For research plot preparation, Pangasius pond water was given to the experimental plot by using power pump. Then plot was tilled by using power tiller machine. Repeated plough was done after 7 days. Plot was labeled by using ladder and weeding was done manually. Then plot became ready to transplant the cuttings of para-grass.

A Completely Randomized Design (CRD) was applied for the experiment of fodder grass production. The experiment had 6 treatments, and each with 3 replications. Thus, the total number of replications was $18(6 \times 3)$ and the size of each replication plot was $25 \mathrm{~m}^{2}$ ( $5 \mathrm{~m} \times 5$ $\mathrm{m})$. A treatment was $0.5 \mathrm{~m}$ far away from another. Well planned dike was constructed around each of the treatments to avoid mixing of nutrients each other. Varied levels of Pangasius pond sediment with inorganic fertilizer were applied in 
Table 1. The experimental design with six treatments

\begin{tabular}{clcc}
\hline Treatments & Treatment description & $\begin{array}{c}\text { Urea } \\
\left(\mathrm{kg} / 25 \mathrm{~m}^{2}\right)\end{array}$ & $\begin{array}{c}\text { Sediment } \\
\left(\mathrm{kg} / 25 \mathrm{~m}^{2}\right)\end{array}$ \\
\hline $\mathrm{T}_{1}$ & Control (No N application just virgin soil in the rice-field) & 0.00 & 0.00 \\
$\mathrm{~T}_{2}$ & $25 \%$ recommended dose of $\mathrm{N}$ & 0.10 & 43.50 \\
$\mathrm{~T}_{3}$ & $50 \%$ recommended dose of $\mathrm{N}$ & 0.19 & 28.50 \\
$\mathrm{~T}_{4}$ & $75 \%$ recommended dose of $\mathrm{N}$ & 0.29 & 14.25 \\
$\mathrm{~T}_{5}$ & $100 \%$ recommended dose of $\mathrm{N}$ & 0.38 & 0.00 \\
$\mathrm{~T}_{6}$ & No fertilizer (100\% mud) & 0.00 & 58.00 \\
\hline
\end{tabular}

each treatment. The doses of Pangasius pond sediment and inorganic fertilizer (urea) are shown in Table 1.

\section{Sediment analysis}

Sediment samples were collected and put in the previously labeled plastic bag and carried to laboratory. Then samples were dried out at room temperature. After drying samples were ground finely and sieved through a $0.03 \mathrm{~mm}$ meshed brass sieve and kept individually in labeled polythene bag for chemical analysis. Pond sediment and soil samples analysis was performed at the Soil Science Laboratory of the Department of Soil Science, Bangladesh Agricultural University (BAU) Mymensingh.

After 45 days of planting, para-grass became ripened and samples from each treatment were collected and marked individually. Rice straw was collected from a cattle farm from the same village. Then well marked samples and straw were carried to the Fish Nutrition Laboratory, Department of Aquaculture, BAU. The grass samples and straw were ground by using a grinding machine. The second samples were taken after 45 days and prepared by following similar way. After the preparation of samples, proximate composition analysis of para-grass samples and rice straw were done by following the official methods of analysis by AOAC (2000). The analyses were performed at the Fish Nutrition Laboratory.

\section{Data analysis}

Statistically, the nutrients content variation between Pangasius pond sediment and plot virgin soil were analyzed using independent sample t-test. Single factor analysis of variance (ANOVA) of the mean values of proximate components was done to test the significance of variation among treatments in terms of nutrient content of para-grass (Steel et al., 1980). Individual treatment difference was analyzed by Duncan's Multiple Range Test (DMRT) at the probability of 0.01 to $0.05 \%$.

\section{Results and Discussion}

\section{Chemistry of Pangasius pond sediment}

The data generated from the laboratory analysis of Pangasius pond sediment and virgin soil was examined statistically. Except $\mathrm{pH}$, the other parameters of Pangasius pond sediment were different statistically from those of virgin soil (Table 2). The mean value $\mathrm{pH}$ of virgin soil and Pangasius pond sediment was $6.8 \pm 0.1$ and $6.86 \pm 0.04$, respectively which were within the suitable range of primary productivity, and more or less similar to the findings of Monir (2009). The finding of the present study did not differ from the finding of Mukta (2008), who observed that the $\mathrm{pH}$ value of Ghatail soil was 6.5. Hossain et al. (2000) reported that the $\mathrm{pH}$ value ranged from 6.02 to 7.10 in the old Brahmaputra floodplain soil. In the present study, the organic carbon content was $1.31 \pm 0.1$ $\%$ in virgin plot soil and $3.15 \pm 0.04 \%$ in Pangasius pond sediment. This finding has a significant importance because organic carbon can play important role in buffering systems, which may regulate $\mathrm{pH}$ value, available phosphorus, organic matter and total nitrogen in soil. The value of total nitrogen was $0.11 \pm 0.01 \%$ and 


\section{Proximate composition of para- grass}

Table 2. Soil chemistry (Mean \pm SD) of plot soil and Pangasius pond sediment

\begin{tabular}{lllllll}
\hline $\begin{array}{l}\text { Soil } \\
\text { Parameters }\end{array}$ & $\mathrm{pH}$ & $\begin{array}{l}\text { Organic } \\
\text { Carbon }(\%)\end{array}$ & $\begin{array}{l}\text { Total } \\
\text { Nitrogen }(\%)\end{array}$ & $\begin{array}{l}\text { Available } \\
\text { Phosphorous } \\
(\mathrm{ppm})\end{array}$ & $\begin{array}{l}\text { Exchangeable } \\
\text { Potassium } \\
(\mathrm{ppm})\end{array}$ & $\begin{array}{l}\text { Available } \\
\text { Sulpher } \\
(\mathrm{ppm})(\%)\end{array}$ \\
\hline $\begin{array}{l}\text { Pangasius } \\
\text { pond }\end{array}$ & $6.86 \pm 0.04$ & $3.15 \pm 0.04$ & $0.30 \pm 0.01$ & $115.6 \pm 0.6$ & $106.8 \pm 4.3$ & $86.06 \pm 0.66$ \\
$\begin{array}{l}\text { sediment } \\
\text { Virgin soil }\end{array}$ & $6.8 \pm 0.1$ & $1.31 \pm 0.1$ & $0.11 \pm 0.01$ & $25.6 \pm 13.0$ & $59.6 \pm 12.5$ & $19.3 \pm 8.6$ \\
$\begin{array}{l}\text { Additional } \\
\text { nutrients } \\
\begin{array}{l}\text { Statistical } \\
\text { significance }\end{array}\end{array}$ & 00.00 & 1.84 & 0.19 & 90.0 & 47.2 & 66.8 \\
\hline
\end{tabular}

Table 3. Composition of para-grass at first sampling, and rice straw

\begin{tabular}{|c|c|c|c|c|c|c|c|}
\hline \multirow{3}{*}{ Ingredients } & \multirow{3}{*}{ Treatments } & \multicolumn{6}{|c|}{ Mean \pm SD } \\
\hline & & $\%$ & $\%$ & $\%$ & $\%$ & $\%$ & $\%$ \\
\hline & & Moisture & Crude lipid & $\begin{array}{l}\text { Crude } \\
\text { protein }\end{array}$ & Ash & Crude fibre & Carbohydrate \\
\hline & $\mathrm{T}_{1}$ & $62.0 \pm 3.20$ & $2.65 \pm 0.11$ & $3.30 \pm 0.28$ & $4.73 \pm 0.44$ & $1.52 \pm 0.02$ & $25.7 \pm 2.60$ \\
\hline & $\mathrm{T}_{2}$ & $59.46 \pm 5.62$ & $2.48 \pm 0.25$ & $3.46 \pm 0.51$ & $4.88 \pm 0.53$ & $1.50 \pm 0.05$ & $28.22 \pm 5.06$ \\
\hline & $\mathrm{T}_{3}$ & $62.06 \pm 0.60$ & $2.57 \pm 0.11$ & $3.39 \pm 0.17$ & $4.89 \pm 0.23$ & $1.55 \pm 0.04$ & $25.55 \pm 0.88$ \\
\hline Para-grass & $\mathrm{T}_{4}$ & $62.06 \pm 0.87$ & $2.45 \pm 0.15$ & $3.22 \pm 0.06$ & $4.72 \pm 0.32$ & $1.49 \pm 0.04$ & $26.07 \pm 0.60$ \\
\hline & $\mathrm{T}_{5}$ & $64.30 \pm 3.44$ & $2.72 \pm 0.32$ & $3.34 \pm 0.36$ & $4.79 \pm 0.57$ & $1.37 \pm 0.02$ & $23.40 \pm 4.10$ \\
\hline & $\mathrm{T}_{6}$ & $57.19 \pm 2.18$ & $2.49 \pm 0.41$ & $3.76 \pm 0.41$ & $4.196 \pm 0.43$ & $1.46 \pm 0.04$ & $30.91 \pm 3.21$ \\
\hline Rice straw & & 20.40 & 2.23 & 3.69 & 6.63 & 1.72 & 65.32 \\
\hline
\end{tabular}

$0.30 \pm 0.01 \%$ in virgin plot soil and Pangasius pond sediment, respectively. The finding of present study was higher than the study of Karim (2009), which denoted the ranges of total nitrogen from 0.043 to $0.096 \%$. Therefore, it can be said that Pangasius pond sediment soil were more productive than the virgin plot soil because the mean value of total nitrogen $(0.30 \pm 0.01)$ was prominent than virgin plot soil $(0.11 \pm 0.01)$. It also indicated that due to addition of Pangasius pond sediment in plot soil, total nitrogen level $(0.19 \%)$ was increased to a greater extent.

Phosphorus is generally considered the second most limiting element for crop. It is one of the major constituents for successful production of upland crop in Bangladesh (Islam, 1983). In the normal field

soil, available phosphorus status was found 720 ppm by Chowdury (1992), which was very closed to the findings of virgin soil of the present study but very less than Pangasius pond sediment (Table 2 ). This result also indicates that the available phosphorus increased in plot soil with application of Pangasius pond sediment. The value of exchangeable potassium was $59.6 \pm 12.5 \mathrm{ppm}$ and 106.8 $\pm 4.31 \mathrm{ppm}$ in plot soil and Pangasius pond sediment, respectively. The value was much higher than the value of the exchangeable potassium content of sonatola soil series. The finding of present study was similar with level of different soil series of Bangladesh, in which the exchangeable potassium ranged from 39.1 to $132.94 \mathrm{ppm}$. The exchangeable potassium increased with the addition of Pangasius pond sediment in plot soil. The available sulphur content was $19.3 \pm 8.6$ in virgin plot soil and $86.06 \pm 0.66$ in Pangasius pond sediment. This result was higher than mean value (16.80 ppm) of available sulphur found in different soil series of Bangladesh. 
Alam et al. (2015) Bang. J. Anim. Sci. 44(2): 11 3- 119

Table 4. Composition of para-grass at second sampling

\begin{tabular}{cccccccc}
\hline Ingredients & Treatments & \multicolumn{7}{c}{ Mean \pm SD } \\
\hline & & $\begin{array}{c}\% \\
\text { Moisture }\end{array}$ & $\begin{array}{c}\% \\
\text { Crude } \\
\text { lipid }\end{array}$ & $\begin{array}{c}\% \\
\text { Crude } \\
\text { protein }\end{array}$ & $\begin{array}{c}\% \\
\text { Ash }\end{array}$ & $\begin{array}{c}\% \\
\text { Crude fibre }\end{array}$ & Carbohydrate \\
\hline Para-grass & $\mathrm{T}_{1}$ & $60.49 \pm 0.19$ & $4.66 \pm 0.69$ & $3.82 \pm 0.19$ & $5.69 \pm 0.36$ & $1.62 \pm 0.04)$ & $23.72 \pm 0.03$ \\
& $\mathrm{~T}_{2}$ & $60.67 \pm 1.83$ & $4.98 \pm 0.89$ & $4.43 \pm 0.31$ & $5.45 \pm 0.25$ & $1.50 \pm 0.13$ & $22.77 \pm 2.50$ \\
& $\mathrm{~T}_{3}$ & $61.57 \pm 0.67$ & $4.75 \pm 0.30$ & $4.51 \pm 0.04$ & $5.28 \pm 0.46$ & $1.61 \pm 0.13$ & $22.28 \pm 1.06$ \\
& $\mathrm{~T}_{4}$ & $56.92 \pm 0.46$ & $4.62 \pm 0.59$ & $4.57 \pm 0.20$ & $5.51 \pm 0.30$ & $1.54 \pm 0.10$ & $26.76 \pm 0.40$ \\
& $\mathrm{~T}_{5}$ & $60.10 \pm 1.50$ & $4.59 \pm 0.26$ & $4.62 \pm 0.23$ & $5.99 \pm 0.44$ & $1.45 \pm 0.14$ & $23.25 \pm 2.03$ \\
& $\mathrm{~T}_{6}$ & $60.25 \pm 0.83$ & $5.22 \pm 1.13$ & $5.48 \pm 0.15$ & $5.91 \pm 0.79$ & $1.82 \pm 0.03$ & $21.32 \pm 2.05$ \\
\hline
\end{tabular}

\section{Nutrient contents of para-grass}

Nutrient content of para-grass is a very important factor to be consider as a cattle feed. The moisture ash, protein, lipid, fibre, carbohydrate content of cattle feed are most important nutrients for their proper growth, maintenance and reproduction.

Generally plant body contains 60 to $70 \%$ moisture. In the present study, it varied from $56.92 \%$ to $61.56 \%$ and $56.92 \%$ to $61.57 \%$ of different treatments of first and second sampling of para-grass, respectively (Table 3 and Table 4). This finding is relevant to the general study. On the other hand, it was found that rice straw contains $20.40 \%$ of moisture (Table 3). In the experiment, ash content of first sampling of para-grass ranged from 4.19 to $4.89 \%$ with mean value of $4.70 \pm 0.67 \%$, and that of second sampling ranged from 5.28 to $5.99 \%$ with mean value of $5.47 \pm 0.99 \%$ (Table 3 and Table 4). Binh (1993) analyzed the plant part of para-grass and found $5.9 \%$ ash content. Abou-ashour (1984) found that ash content of Napier grass ranged from 9.38 to $11.26 \%$. Bhuian (2002) found $12.29 \%$ ash content of rice straw and the current research finding is $6.63 \%$ (Table 3 ), which is relatively lower than Bhuian (2002).

Protein is the most important parameter of nutritional quality of fodders. It varied from 3.22 to $3.76 \%$ with mean value of $3.41 \pm 0.54 \%$, and 3.82 to $5.48 \%$ with mean value of $4.43 \pm 0.41 \%$ in first and second sampling of para-grass, respectively (Table and Table 4). Binh (1993) analyzed the plant part of para-grass and found crude protein was relatively high $(14.58 \%)$ in the leaves while in the stem was law (4.49\%). Mohan et al. (1977) determined the protein content at $4.8 \%$. By comparing, it can be argued that the present finding has harmony with relevant references. In the present study, the crude protein of rice straw is $3.69 \%$ (Table 3 ) which is almost similar to Bhuian (2002), as reported at $4.12 \%$. This result also shows that, crude protein is relatively high in para-grass than rice straw.

Crude lipid is considerably high in second sampling than first sampling of para-grass. Crude lipid of first sampling varies from 2.44 to $2.72 \%$ with mean value $2.56 \pm 0.38 \%$ and that of second sampling varied from 4.66 to $5.22 \%$ with mean value $4.94 \pm 1.17 \%$ (Table 3 and Table 4). This might be due to the environmental factors which stimulated paragrass to uptake more nutrients from the soil to accumulate lipid. Mohan et al. (1977) determined the lipid content of green fodders at $1.73 \%$. Gill et al. (1979) measured the nutritive value of fodder at the stages of pre-bloom; bloom, mature and stover containing lipid of $2.1,1.6,1.6$ and $1.4 \%$, respectively. In the study, it was found $2.23 \%$ crude lipid of rice straw (Table 3) which is relatively lower than that of para-grass. Bhuian (2002) stated that, rice straw contain $2.17 \%$ crude lipid. Feeding dairy cattle with higher lipid containing fodder grass has impacts on enhancing milk production. 


\section{Proximate composition of para-grass}

Fibre content was considerably higher in second sampling than first sampling of para-grass. It varied from 1.37 to $1.55 \%$ with mean value of $1.48 \pm 0.07 \%$, and 1.45 to $1.82 \%$ with mean value of $1.58 \pm 0.20 \%$ in first and second sampling, respectively. Fibre content of rice straw was $1.72 \%$ which was closed to the finding of para-grass (Table 3 ). Carbohydrate content varied from 23.40 to $30.91 \%$ with mean value of $26.81 \pm 5.40 \%$, and 21.32 to $26.76 \%$ with mean value of $23.56 \pm 3.05 \%$ for first and second sampling, respectively (Table 3 and Table 4). Gupta et al. (1975) found 22.3 to $35.5 \%$ dry matter and 19.45 to $36.5 \%$ cellulose analyzing 18 important grasses. Feed scarcity and low quality rice straw based diets have been identified as the main constraint for milk and meat production in Bangladesh. Straw is low in nitrogen and having low digestibility due to high content of lignin in cell wall structure (Khan and Uddin, 2012). According to Lend (1995), straw is characterized by highly lignified cell wall with poor contents of protein and lipid, and storage of carbohydrate resulting slow digestibility and poor performance of the cattle. The present findings are supported by these statements. This study proved that protein and lipid content was higher in para-grass than rice straw. In order to overcome the limitation of rice straw and its nutrient deficiencies, supplementation with fodder (para-grass) should be emphasized in feeding of cattle.

\section{Conclusion}

The nutrient content of para-grass was higher for the application of Pangasius pond sediment because pond sediment acted as a major source of nutrient for the grass production. After addition of pond sediment into soil, the productivity of soil was increased and ultimately increased the growth of grass and enriched nutrient in plant body. If a national strategy has taken holistic aquaculture development, the huge amount unused Pangasius pond sediment could be used to fertilize fodder grass for dairy cattle, and other crop production as part of integrated aquaculture - livestock -agriculture systems.

\section{References}

Abou-ashour (1984). Evaluation of nutritive value of Napier grass. Tropical Grasses. P. 240-243.

AOAC (2000). Official Methods of Analysis, Seventeenth edition. Association of Official Analytical Chemists. Washington, DC.

Bhuian AA (2002). Nutritive value of damp rice straw and its feeding effect on aflatoxin transmission into cow's milk. MS Thesis. Department of Animal Husbandry, BAU, Mymensingh. pp.31.

Binh LH (1993). Forage productivity of paragrass in Vietnam. National Institute of Animal Husbandry, Hanoi-Vietnam.

Boyd CE (1995). Bottom soil, sediment and pond aquaculture, Chapman\& Hall, New York, 5: (348).

Chowdury AH (1992). To study the physical and chemical properties of two AEZ of Bangladesh under three cropping patterns. MS Thesis. Department of Soil Science, (BAU) Mymensingh. pp.93.

FAO Fisheries and Aquaculture Department (2013). Global Aquaculture Production Statistics for the Year 2011.

Gill AE (1979). Integration of fodder production. Philippine Journal of Crop Science, 1: 137138

Gupta PC, Singh R, Singhi K and Prandhan K (1975). Chemical composition and in-virto dry matter digestibility of some important grasses. Herbage Abstract, 46: 332.

Haque MM (2011). Bag gardening by using Pangasius pond sediment. The National Fish Week, Proceedings in Bangla, Department of Fisheries, Ministry of Fisheries and Livestock, Matsya Bhaban, Dhaka, Bangladesh.

Hossain MY (2000). Effects of iso-phosphrus organic and inorganic fertilizers on water quality parameters and biological production. MS Thesis. Department of Fisheries Management, BAU, Mymensingh, pp. 24.

Karim MR (2009). Properties of some selected soil series of floodplain and Hill soils of Bangladesh. MS Thesis. Department of Soil Science (BAU), Mymensingh, pp. 43. 
Khalifa HAA (1974). A study of the nutritive value of para-grass. Nutrition Abstract, 46: 176.

Khan MAS and Uddin ME (2012). Dairy cattle production: major constraints and its solutions. Proceedings of the seminar, $1^{\text {st }}$ international exhibition on dairy, aqua and pet animal-2012. pp. 1-6

Leng RA (1995). Trees- their role in animal nutrition in developing countries in the humid tropics. In: Recent advance in animal nutrition in Australia. University of New England publishing unit, Armidale NSW 2351, Australia. pp. 149-159.

Mohan RE and Cowdry WAR (1977). Yield from irrigated pasture in Bardekin. Queensland Journal of Agricultural and Animal Science, 1: $137-138$
Monir MS (2009). A study on the technical aspects of Pangasius farming in Mymensingh region, MS Thesis. Department of Aquaculture, BAU Mymensingh, pp. 58.

Mukta MA (2008). Fertility status of some soils of Bangladesh. MS Thesis. Department of Soil Science, (BAU) Mymensingh, pp. 68.

Olah J, Pekar F and Szabo P (1994). Nitrogen cycling and retention in fish cum livestock Ponds. Journal of Applied Ichthyology, 10: (341-348).

Steel RGD, Torrie JH (1980). Principles and Procedures of Statistics. MacGraw-Hill Book Company, Inc. New York. 